\title{
Acute Toxicity of Mixtures of Range Management Herbi- cides to Cutthroat Trout
}

DANIEL F. WOODWARD

\section{Abstract}

Six different paired mixtures of dicamba, picloram, 2,4-D butyl ester, 2,4-D isooctyl ester, and 2,4-D propylene glycol butyl ether ester were tested with cutthroat trout (Salmo clarki). Except for 2,4-D isooctyl ester, the LC50's resulting from mixtures of 2,4-D esters and picloram were lower than LC50's of those herbicides tested individually. Dicamba and 2,4-D isooctyl ester were the least toxic individually and mixtures of dicamba or 2,4-D isooctyl ester with the other herbicides tested did not result in increased toxicity. Our results reflect the importance of using combination exposures in determining the biological significance of the simultaneous occurrence of more than one herbicide in surface waters.

Inasmuch as the application of herbicides is currently the most popular and effective method used by range managers to control weeds, there is a need to determine the effect of these herbicides on stream organisms. Woodward (1979) described the potentially adverse effects of one important herbicide, picloram (Tordon), to cutthroat trout (Salmo clarki) under simulated field conditions. One of the recommendations developed from this research was that, in areas where picloram is applied, alternate herbicides should be used next to aquatic environments. This recommendation could result in simultaneous applications of more than one herbicide and create a potential for the simultaneous entry of more than one herbicide into an aquatic habitat. Therefore, the effects of combinations of range management chemicals on a fishery should be evaluated.

The author is U.S. Fish and Wild life Service, Columbia National Fisheries Research Laboratory, Field Research Laboratory-Jackson, P.O. Box 1089, Jackson, Wyo. 83001 .

Manuscript received February 6, 1981

\section{Materials and Methods}

Cutthroat trout were selected for this study because they are native sportfish in intermountain rangeland streams. Fingerlings ( 0.4 to $0.8 \mathrm{~g}$ ) were obtained from the Jackson (Wyoming) National Fish Hatchery and maintained according to the procedures of Brauhn and Schoettger (1975). Technical grade dicamba (88\%) was obtained from Velsicol Chemical Corporation. The other herbicides were obtained in their technical form from Dow Chemical Company: $2,4-\mathrm{D}$ BE (98.4\% ester and $78.5 \%$ acid equivalent), 2,4-D IOE ( $99.6 \%$ ester and $66.1 \%$ acid equivalient), 2,4-D PGBEE ( $100 \%$ ester and $61.7 \%$ acid equivalent), picloram $(90 \%)$. Test concent rations were based on active ingredient and stock solutions were prepared in acetone or water within 1 week of exposure.

Toxicity of single herbicides was tested according to the Committee on Methods for Toxicity Tests with Aquatic Organisms (1975). Toxicity tests of herbicide mixtures were performed as a single herbicide exposure, except that two herbicides were simultaneously added to the test container in a $1: 1$ ratio of their $96-h$ I.C50's. For example, if the 96-h LC50's of herbicides A and B were 10 and 20 units individually, then the mixture test concentrations of $A$ and $B$ were prepared in a 1:2 ratio. Herbicides having LC50's greater than $50 \mathrm{mg} / 1$ were tested in all mixtures at concentrations of $50 \mathrm{mg} / \mathrm{l}$. Herbicides with LC50's greater than $50 \mathrm{mg} / \mathrm{l}$ were not tested with each other because herbicide concentrations greater than $50 \mathrm{mg} / \mathrm{l}$ are rare in natural streams and solubility problems would develop with some herbicides when testing at concentrations greater than $50 \mathrm{mg} / \mathrm{l}$. Since formulations of 2,4-D are not normally applied in combination with each other, mixtures of different esters of 2,4-D were not tested. The Litchfield and Wilcoxon (1949) method was used to determine 96-h LC50's for each herbicide in a mixture and for each herbicide tested singly, and to compare differences between two LC50s. 
Table 1. Acute toxicity (96-LC50) of selected herbicides, individually and in paired mixtures, to cutthroat trout.

\begin{tabular}{|c|c|c|}
\hline \multirow[b]{2}{*}{ Herbicide mixture ${ }^{a}$} & \multicolumn{2}{|c|}{$\begin{array}{l}\text { LC50 and (in parenthesis) } 95 \% \text { confidence inter- } \\
\text { val }(\mathrm{mg} / 1)\end{array}$} \\
\hline & Individually & In combination \\
\hline 2,4-D BE & $\begin{array}{c}0.78 \\
(0.66-0.92)\end{array}$ & $\begin{array}{c}0.50 \\
(0.43-0.58)\end{array}$ \\
\hline $\begin{array}{l}\text { and } \\
\text { Picloram }\end{array}$ & $\begin{array}{c}4.5 \\
(3.8-5.3)\end{array}$ & $\begin{array}{c}2.5 \\
(2.1-2.9)\end{array}$ \\
\hline 2,4-D PGBEE & $\begin{array}{c}0.77 \\
(0.62-0.96)\end{array}$ & $\begin{array}{c}0.40 \\
(0.32-0.50)\end{array}$ \\
\hline $\begin{array}{l}\text { and } \\
\text { Picloram }\end{array}$ & $\begin{array}{c}4.5 \\
(3.8-5.3)\end{array}$ & $\begin{array}{l}2.0 \\
(1.6-2.5)\end{array}$ \\
\hline $\begin{array}{l}\text { 2,4-D IOE } \\
\text { and }\end{array}$ & $>50$ & $>50$ \\
\hline Picloram & $\begin{array}{l}3.9 \\
(3.2-4.8)\end{array}$ & $\begin{array}{c}3.1 \\
(2.6-3.7)\end{array}$ \\
\hline $\begin{array}{l}\text { 2,4-D BE } \\
\text { and }\end{array}$ & $\begin{array}{c}0.78 \\
(0.67-0.91)\end{array}$ & $\begin{array}{c}0.78 \\
(0.67-0.91)\end{array}$ \\
\hline $\begin{array}{l}\text { Dicamba } \\
\text { 2,4-D PGBEE }\end{array}$ & $\begin{array}{c}>50 \\
0.79 \\
(0.67-0.93)\end{array}$ & $\begin{array}{c}>50 \\
1.1 \\
(0.89-1.2)\end{array}$ \\
\hline $\begin{array}{l}\text { and } \\
\text { Dicamba }\end{array}$ & $>50$ & $>50$ \\
\hline $\begin{array}{l}\text { Dicamba } \\
\text { and }\end{array}$ & $>50$ & $>50$ \\
\hline Picloram & $\begin{array}{c}3.9 \\
(3.2-4.8)\end{array}$ & $\begin{array}{c}4.0 \\
(3.4-4.8)\end{array}$ \\
\hline
\end{tabular}

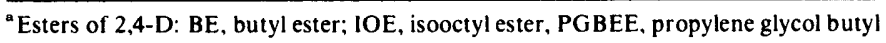
ester.

\section{Results and Discussion}

The LC50's of 2,4-D BE and 2,4-D PGBEE to cutthroat trout were similar, 0.78 and $0.77 \mathrm{mg} / \mathrm{l}$ (Table 1); in combination with picloram toxicities of both esters increased significantly $(P \leq 0.05)$. Similarly, the toxicity of picloram increased. Marking and Dawson (1975), working with fish toxicants, found individual contaminants in a mixture are lethal at lower concentrations than singly because of the combined toxicity of each component in the mixture. My findings indicate that 2,4-D BE and 2,4-D PGBEE would have a greater adverse affect on a cutthroat fishery when used simultaneously with picloram than when they are used alone. Similarly, picloram would be a greater hazard to cutthroat trout when it is used with either 2,4-D BE or 2,4-D PGBEE than when it is used alone.

In the 2,4-D IOE and picloram mixture test the LC50 of the 2,4-D IOE did not decrease below $50 \mathrm{mg} / \mathrm{l}$ and the toxicity of the picloram did not change significantly $(P>0.05)$. Also, the LC50 of dicamba was greater than $50 \mathrm{mg} / \mathrm{l}$, whether alone or in combination with 2,4-D BE, 2,4-D PGBEE, or picloram. A concentration of $50 \mathrm{mg} / 1$ dicamba did not significantly $(P>0.05)$ alter the toxicity of 2,4-D BE, 2.4-D PGBEE, or picloram. Thus 2,4-D IOE and dicamba do not appear to pose a threat to the cutthroat fisheries, nor would combined application of dicamba or 2,4-D IOE with the other herbicides tested increase toxicity.

Woodward (1979) and Woodward and Mayer (1978) recommended that buffer zones be maintained between aquatic habitats and areas where 2,4-D BE, 2,4-D PGBEE or picloram are applied. When control of vegetation is necessary in such buffer zones, dicamba and 2,4-D IOE would be the preferred herbicide from the standpoint of protecting the aquatic resource.

Predictions of biological effects based on water concentration and tests of individual herbicides may be eroneous when mixtures of herbicides are applied, or when different herbicides are applied on different parts of the same watershed. Resource managers should be aware that the toxicity of a herbicide in a mixture can differ from its individual toxicity. When the potential for mixtures of herbicides exists, the concentration of all herbicides should be determined; biological hazard can be predicted only from studies involving combination exposures.

\section{Literature Cited}

Alley, H.P., and N.E. Humburg. 1979. Wyoming weed control guide. 1979. Univ. Wyoming Agr. Ext. Serv. Bull. 442R 63 p.

Brauhn, J.L., and R.A. Schoettger. 1975. Acquisition and culture of research fish: rainbow trout, fathead minnows, channel catfish, and bluegills. Ecol. Res. Ser. EPA-660/3-75-011. 45 p.

Committee on Methods for Toxicity Tests with Aquatic Organisms. 1975. Methods for acute toxicity tests with fish, macro-invertebrates, and amphibians. Ecol. Res. Ser. EPA-660/3-75-009. 61 p.

Litchfield, J.T., Jr., and F. Wilcoxon. 1949. A simplified method of evaliating dose-effect experiments. J. Pharmacol. Exp. Therap. 96-99-113.

Marking, L.L., and V.K. Dawson. 1975. Method for assessment of toxicity of efficacy of mixtures of chemicals. U.S. Fish Wildl. Serv., Invest. in Fish Control 67. 8 p.

Woodward, D.F. 1976. Toxicity of the herbicides dinoseb and picloram to cutthroat trout and lake trout. J. Fish. Res. Board Can. 33:1671-1676.

Woodward, D.F. 1979. Assessing the hazard of picloram to cutthroat trout. J. Range Manage. 32:230-232.

Woodward, D.F., and F.L. Mayer, Jr. 1978. Toxicity of three herbicides (butyl, isooctyl, and propylene glycol butyl ether esters of 2,4-D) to cutthroat trout and lake trout. U.S. Fish Wild. Serv. Tech. Pap.97. 6 p. 